\title{
STUDI LITERATUR RISET MANAGEMENT CONTROL FOR SUSTAINABILITY 2010-2019
}

\author{
SeTin SeTin', Santy Setiawan², Yunita Christy ${ }^{3}$ \\ Universitas Kristen Maranatha, Program Studi Akuntansi \\ email: setin2005@yahoo.com,santy_jc@yahoo.com,cuynit@yahoo.com*
}

\begin{abstract}
The purpose of this paper is to review management control for sustainability research for the period 2010-2019. This study applied a descriptive approach to answer about the motivation (research objectives), the theory; the research method used; research findings and research agenda. Management control for sustainability research development was traced through article published in Schimago journal rank (SJR) namely Management Accounting Research dan Journal of Management Accounting Research. The unit of analysis is a journal containing articles management accounting issues and sustainability issues. A total of 344 articles were examined that resulted in 6 articles for analysis. Some findings are, first, research into sustainability control systems focused on environmental sustainability; discuss the role of management control systems in managing social responsibility strategies; and examine the relationship between external pressures and sustainability control systems. Second, the theories used are configuration theory, institutional theory, institutional logic, the framework of the four control levers, the environmental management control system; third, quantitative, qualitative, and content analysis methods are used in research; fourth, generally analysis at managerial level; fifth, using primary data and secondary data.
\end{abstract}

Keywords: Sustainability; Management Control System

\begin{abstract}
Abstrak
Tujuan studi ini adalah meninjau riset pengendalian manajemen untuk keberlanjutan pada periode 2010-2019. Studi ini menerapkan pendekatan deskriptif untuk menjawab tentang motivasi (tujuan penelitian), teori, metode penelitian yang digunakan, temuan penelitian dan agenda penelitian. Riset pengendalian manajemen untuk keberlanjutan ditelusuri melalui artikel yang diterbitkan dalam Schimago journal rank (SJR) yaitu Management Accounting Research dan Journal of Management Accounting Research. Unit analisis adalah artikel topik akuntansi manajemen dan isu keberlanjutan. Sebanyak 344 artikel diperiksa dan diperoleh 6
\end{abstract}


artikel untuk direviu. Beberapa temuan adalah, pertama, penelitian tentang sistem kontrol keberlanjutan fokus pada kelestarian lingkungan; membahas peran sistem kontrol manajemen dalam mengelola strategi tanggung jawab sosial; dan menguji hubungan antara tekanan eksternal dengan sistem kontrol keberlanjutan. Kedua, teori yang digunakan adalah teori konfigurasi, teori kelembagaan, logika kelembagaan, kerangka kerja dari empat tuas kontrol, sistem kontrol manajemen lingkungan; ketiga, metode analisis kuantitatif, kualitatif, dan analisis konten digunakan dalam penelitian; keempat, umumnya analisis pada tingkat manajerial; kelima, menggunakan data primer dan data sekunder.

Kata kunci: Keberlanjutan; Sistem Pengendalian Manajemen

\section{PENDAHULUAN}

Dekade terakhir, perusahaan menghadapi harapan dan tekanan dari berbagai komunitas (pemerintah, lembaga swadaya masyarakat, opini publik, dan sebagainya) tentang aturan bisnis terkait sosial dan lingkungan (Smith \& Sharicz, 2011). Perusahaan harus memperhatikan tidak hanya konsekuensi ekonomi dari kegiatan mereka, tetapi juga beroperasi dengan cara yang bertanggung jawab terhadap sosial dan lingkungan. Harapan dan tekanan ini tidak lagi dapat diabaikan perusahaan. Perusahaan harus menerima gagasan bahwa bisnis memainkan lebih dari sekedar peran ekonomi dalam masyarakat, tetapi juga bertanggung jawab terkait dampak pada masyarakat dan lingkungan (Cresti, 2009). Tanggung jawab yang lebih luas ini mengacu pada keberlanjutan (sustainability). Keberlanjutan menunjukkan dimasukkannya kepedulian sosial dan lingkungan ke dalam operasi bisnis dan interaksi dengan pemangku kepentingan.

Menanggapi tanggungjawab terhadap lingkungan dan sosial, perusahaan mulai mengakui pentingnya keberlanjutan dan merangkul retorika keberlanjutan dalam wacana mereka (Gond et al., 2012). Namun, penerapan keberlanjutan yang strategis masih sulit dilakukan, karena: pertama, pemahaman perusahaan dan pemangku kepentingan tentang keberlanjutan masih belum seragam dan konsisten dengan pemahaman di tingkat global; kedua, sebagian besar perusahaan masih terjebak dalam kegiatan donasi yang hanya menonjolkan kegiatan sosial tanpa membuat perbaikan substansial pada pengendalian operasional perusahaan secara keseluruhan (Wahyuni, 2015). Dengan kata lain, perusahaan bermasalah dengan pengendalian manajemen terkait keberlanjutan (management control for sustainability).

Begitu banyak tuntutan dan tekanan para pemangku kepentingan terhadap integrasi keberlanjutan ke dalam strategi dan agenda perusahaan (Herreman et al., 2015; Perez-Lopez et al., 2013; Searcy, 2012), menyebabkan kebutuhan akan penelitian di bidang ini menjadi sangat mendesak. Walaupun ada peningkatan

* Corresponding author's e-mail: cuynit@yahoo.com http://openjournal.unpam.ac.id/index.php/JABI 
Jurnal Akuntansi Berkelanjutan Indonesia - Vol. 4, No. 1, Jan 2021 - SeTin; Setiawan \& Christy

penelitian akuntansi keberlanjutan (sustainability accounting), misalnya Burritt \& Schaltegger 2010; Gray 2010; Hopwood et al., 2010, namun riset yang ada umumnya fokus pada pelaporan eksternal dan masih sangat terbatas yang membahas pengendalian manajemen internal.

Banyak peneliti berpendapat bahwa sistem pengendalian manajemen (management control system-MCS) berperan utama dalam mengintegrasi secara efektif masalah keberlanjutan ke dalam manajemen bisnis (Durden, 2008; Rahbek \& Neergaard, 2008). Akan tetapi, sedikit informasi tentang bagaimana sistem kontrol perusahaan berkontribusi dalam masalah keberlanjutan (Gond et al., 2012). Studi ini bermaksud menjelaskan perkembangan penelitian topik pengendalian manajemen yang mendukung keberlanjutan (management control for sustainability) selama satu dekade terakhir (2010-2019). Hasil studi berkontribusi memberikan pengetahuan dan pemahaman kepada praktisi dan peneliti di bidang akuntansi manajemen tentang perkembangan penelitian topik pengendalian manajemen untuk keberlanjutan dan menarik perhatian peneliti untuk melakukan studi lebih lanjut pada area ini.

Studi ini menjawab pertanyaan berikut:

1. Motivasi dan/ tujuan studi

2. Teori yang digunakan di dalam studi management control for sustainability

3. Temuan/ hasil studi yang telah dilakukan

4. Metode penelitian (jenis penelitian, jenis data, metode pengumpulan data, alat analisis, sampel, level/unit analisis)

5. Agenda riset management control for sustainability

\section{KERANGKA TEORITIS DAN PENGEMBANGAN HIPOTESIS}

\section{Traditional Management Control Systems dan Management Control for Sustainability (SCS)}

Management control system (MCS) tradisional mengacu pada rutinitas dan prosedur berbasis informasi yang digunakan manajer untuk mempertahankan atau mengubah pola kegiatan organisasi (Simon, 1995). MCS tradisional fokus pada pertumbuhan dan profitabilitas melalui peningkatan efisiensi biaya. MCS tradisional terbatas dalam menggabungkan kepentingan berbagai pemangku kepentingan dan terbatas dalam menangani masalah lingkungan dan sosial (Burritt \& Schaltegger, 2010; Herzig et al., 2012).

MCS tradisional terdiri dari kontrol formal dan informal. Kontrol formal mengacu pada kewajiban kontraktual yang terdiri dari peraturan, evaluasi kinerja, kriteria penghargaan dan sistem penganggaran untuk mengendalikan hasil melalui umpan balik (Norris \& O'Dwyer, 2004). Kontrol informal meliputi kepercayaan, nilai bersama, norma, budaya, tradisi, dan pengendalian diri. Kontrol informal kurang

* Corresponding author's e-mail: cuynit@yahoo.com http://openjournal.unpam.ac.id/index.php/JABI 
Jurnal Akuntansi Berkelanjutan Indonesia - Vol. 4, No. 1, Jan 2021 - SeTin; Setiawan \& Christy

terlihat dan mungkin tidak sengaja dirancang untuk mencapai tujuan organisasi sehingga tidak seefektif kontrol yang formal (Langfield-Smith, 1997).

Gagasan tentang keberlanjutan adalah gagasan yang sangat kompleks dan sarat nilai (Byrch et al, 2007). Keberlanjutan mengacu pada kegiatan yang memasukkan kepedulian sosial dan lingkungan serta interaksi pemangku kepentingan ke dalam operasi bisnis. Memasukkan isu sosial dan lingkungan serta kebutuhan pemangku kepentingan ke dalam strategi perusahaan, budaya, sistem manajemen, proses bisnis dan pengambilan keputusan adalah cara untuk tetap kompetitif dalam konteks global dan mencapai keberhasilan jangka panjang (Porter \& Kramer, 2007).

Organisasi yang bertujuan menerapkan keberlanjutan mengubah sistem kontrol manajemen tradisional. Ball \& Milne (2005) menjelaskan bahwa gagasan baru pengendalian manajemen adalah sangat penting dalam konteks pergeseran menuju keberlanjutan. Perusahaan mengadopsi perspektif holistik mengenai kontrol untuk keberlanjutan yaitu memahami kontrol sebagai sebuah 'paket' yang terdiri dari perencanaan strategis, penganggaran, sistem pengukuran keuangan, sistem pengukuran non-keuangan, sistem pengukuran hybrid (campuran ukuran keuangan dan non keuangan), manajemen proyek, serta evaluasi dan penghargaan (Malmi \& Brown, 2008).

Gond et al, 2012 mendeskripsikan sistem kontrol keberlanjutan dengan tujuh cakupan, yaitu pertama, perencanaan strategis mengacu pada sistem pengendalian manajemen yang terkait dengan perencanaan jangka panjang berdasarkan perkiraan lingkungan kompetitif; kedua, penganggaran mengacu pada sistem pengendalian manajemen yang terkait dengan rencana penetapan tujuan; ketiga, sistem pengukuran keuangan mengacu pada sistem pengendalian manajemen yang terkait dengan informasi keuangan yang lebih spesifik daripada yang terkandung dalam anggaran (misalnya informasi return on investment (ROI) dan economic value added (EVA); keempat, sistem pengukuran non-keuangan misalnya, pengenalan produk baru dan posisi pasar; kelima, sistem pengukuran hybrid yang mengacu pada sistem pengendalian manajemen yang menggabungkan indikator keuangan dan nonkeuangan untuk menilai pencapaian tujuan strategis (misalnya, balanced scorecard); keenam, manajemen proyek yang mengacu pada sistem pengendalian manajemen yang terkait dengan ketepatan waktu dan keketatan anggaran; ketujuh, evaluasi dan penghargaan mengacu pada sistem pengendalian manajemen yang terkait dengan mengarahkan upaya individu dan grup di dalam organisasi (misalnya pembayaran bonus).

Telah banyak wacana yang menjelaskan tentang pentingnya management control for sustainability (SCS). Beberapa diantaranya adalah SCS berperan penting memastikan bahwa kegiatan lingkungan dan sosial dimasukkan ke dalam rencana dan tujuan strategis organisasi (Adams \& McNicholas, 2007; Gond et al., 2012). SCS berperan dalam integrasi masalah keberlanjutan ke dalam manajemen bisnis (Durden, 2008; Rahbek \& Neergaard, 2008). SCS memberi informasi kepada manajer dan

* Corresponding author's e-mail: cuynit@yahoo.com http://openjournal.unpam.ac.id/index.php/JABI 
Jurnal Akuntansi Berkelanjutan Indonesia - Vol. 4, No. 1, Jan 2021 - SeTin; Setiawan \& Christy

melibatkan pemangku kepentingan dalam keputusan menerapkan strategi tanggungjawab sosial (Schaltegger \& Burritt, 2010). SCS mendukung informasi penggunaan sumber daya dan biaya sumber daya yang berdampak pada lingkungan (Bartolomeo et al., 2000).

Untuk menanggapi tekanan terhadap keberlanjutan, berbagai sistem kontrol akuntansi keberlanjutan juga telah dikembangkan dan diimplementasi oleh organisasi, yaitu perencanaan keberlanjutan (Bonacchi \& Rinaldi, 2007); penganggaran lingkungan (Burritt \& Schaltegger, 2010); penganggaran berkelanjutan (Roth, 2008); sistem akuntansi biaya lingkungan (Herzig et al., 2012); nilai tambah berkelanjutan (Figge et al., 2002); sistem evaluasi kinerja lingkungan (Dias-Sardinha et al., 2002); pengukuran kinerja keberlanjutan (Schaltegger \& Wagner, 2006); keberlanjutan balanced scorecard (Hubbard, 2009); analisis sosio-eko-efisiensi (Schmidt et al., 2004); penilaian investasi lingkungan (Burritt et al., 2009); sistem kinerja multidimensi (Dutta \& Lawson, 2009).

Penelitian tentang MCS untuk keberlanjutan atau SCS adalah tema yang terus mencuat (Berry et al., 2009). Sejak awal 1990-an, literatur CSR telah memberi isyarat pentingnya memiliki alat manajerial khusus yang ditujukan untuk mengukur kinerja berkelanjutanyang mewakili perspektif lingkungan dan sosial (Epstein \& Roy, 2001). Banyak penulis telah menyarankan penggunaan balanced scorecard (BSC) sebagai alat yang efektif untuk mendukung keberlanjutan (misalnya Songini \& Pistoni, 2012; Bonacchi \& Rinaldi, 2007). BSC yang berkelanjutan dapat dirancang mengikuti pendekatan triple bottom line (Elkington, 1997). Penelitian lain, yaitu Gond et al. (2010) mengenalkan peran dan kegunaan sistem kontrol manajemen (MCS) dan sistem kontrol keberlanjutan (SCS) dalam proses pembaruan strategis. Gond et al., (2010) konsisten dengan Epstein \& Wisner, 2001 yang mempertimbangkan strategi sosial dan mengusulkan penggunaan dua sistem kontrol yaitu MCS dan SCS. Studi lain adalah tentang sistem manajemen lingkungan (EMS) yang menggabungkan mekanisme tradisional, termasuk penganggaran, sistem pengukuran kinerja, dan proses manajemen risiko yang umum digunakan dalam bisnis namun disesuaikan untuk menangani masalah spesifik yang terkait dengan isu lingkungan (Henri \& Journeaut, 2010).

Gond et al., (2010) berargumen bahwa walaupun organisasi mungkin telah memasukkan retorika keberlanjutan dalam pelaporan eksternal dan dalam pernyataan misi mereka, akan tetapi sedikit bukti tentang peran sistem kontrol manajemen yang mendukung keberlanjutan di dalam organisasi. Pemahaman yang lebih luas tentang bagaimana MCS memungkinkan manajer mengendalikan dan memantau strategi CSR diperlukan untuk memberikan wawasan mengenai peran MCS dalam mengubah praktik bisnis dan dalam mengelola ancaman dan peluang yang terkait tanggungjawab sosial dan lingkungan. Penelitian tentang sistem kontrol manajemen yang mendukung keberlanjutan sangat penting untuk memberi kontribusi terhadap keberlanjutan organisasi.

* Corresponding author's e-mail: cuynit@yahoo.com http://openjournal.unpam.ac.id/index.php/JABI 
Jurnal Akuntansi Berkelanjutan Indonesia - Vol. 4, No. 1, Jan 2021 - SeTin; Setiawan \& Christy

\section{METODE RISET}

Tulisan ini mendeskripsikan riset management control for sustainability selama satu dekade terakhir (2010-2019). Data diperoleh dari artikel topik management control for sustainability yang diterbitkan pada jurnal yang masuk dalam schimago journal rank (SJR) dengan kategori subjek akuntansi manajemen. Deskripsi dilakukan dengan menjawab pertanyaan, yaitu pertama, motivasi/tujuan studi; kedua teori yang digunakan di dalam studi management control for sustainability; ketiga, temuan/ hasil studi; keempat, dan metode penelitian (jenis penelitian, jenis data, metode pengumpulan data, alat analisis, sampel, level/unit analisis); kelima, agenda riset management control for sustainability.

\section{ANALISI DATA DAN PEMBAHASAN}

Riset management control for sustainability ditelusuri melalui artikel yang diterbitkan pada jurnal yang masuk dalam schimago journal rank (SJR), yang khusus mempublikasikan artikel di bidang akuntansi manajemen. Melalui http://www.scimagojr.com/journalrank.php?category=1402, ditemukan dua jurnal SJR quartile Q1 dan Q2 yang sesuai dengan kriteria, yaitu Management Accounting Research dan Journal of Management Accounting Research. Studi ni menggunakan kata kunci 'sustainability, management control system' untuk mencari artikel. Artikel dicari secara online di setiap jurnal melalui https://www.journals.elsevier.com/management-accountingresearch dan http://aaapubs.org/loi/jmar?code=aaan-site. Data dikumpulkan selama November 2019-Desember 2019 dari jurnal yang diterbitkan selama periode 2010-2019. Sebanyak 344 artikel diperiksa yang menghasilkan 6 artikel untuk dijelaskan.

Table 1. Hasil Pencarian artikel topik Management Control for Sustainability, dari Schimago Journal Rank (SJR), Periode 2010-2019

\begin{tabular}{|c|c|c|c|c|c|}
\hline No & Schimago Journal Rank (SJR) & Tahun & Volume & $\sum$ Artikel & $\begin{array}{c}\text { Kata Kunci } \\
\text { "Sustainability } \\
\text { Control } \\
\text { System" } \\
\end{array}$ \\
\hline \multirow[t]{6}{*}{1} & Management Accounting Research & 2010 & Vol 21 & & \\
\hline & (SJR quartile Q1, Country: United States; & & No. 1-4 & 20 & 0 \\
\hline & Publisher: Elsevier Inc) & 2011 & Vol 22 & & \\
\hline & & & No. $1-4$ & 21 & 0 \\
\hline & & 2012 & Vol 23 & & \\
\hline & & & No. $1-4$ & 17 & 1 \\
\hline
\end{tabular}

* Corresponding author's e-mail: cuynit@yahoo.com http://openjournal.unpam.ac.id/index.php/JABI 
Jurnal Akuntansi Berkelanjutan Indonesia - Vol. 4, No. 1, Jan 2021 - SeTin; Setiawan \& Christy

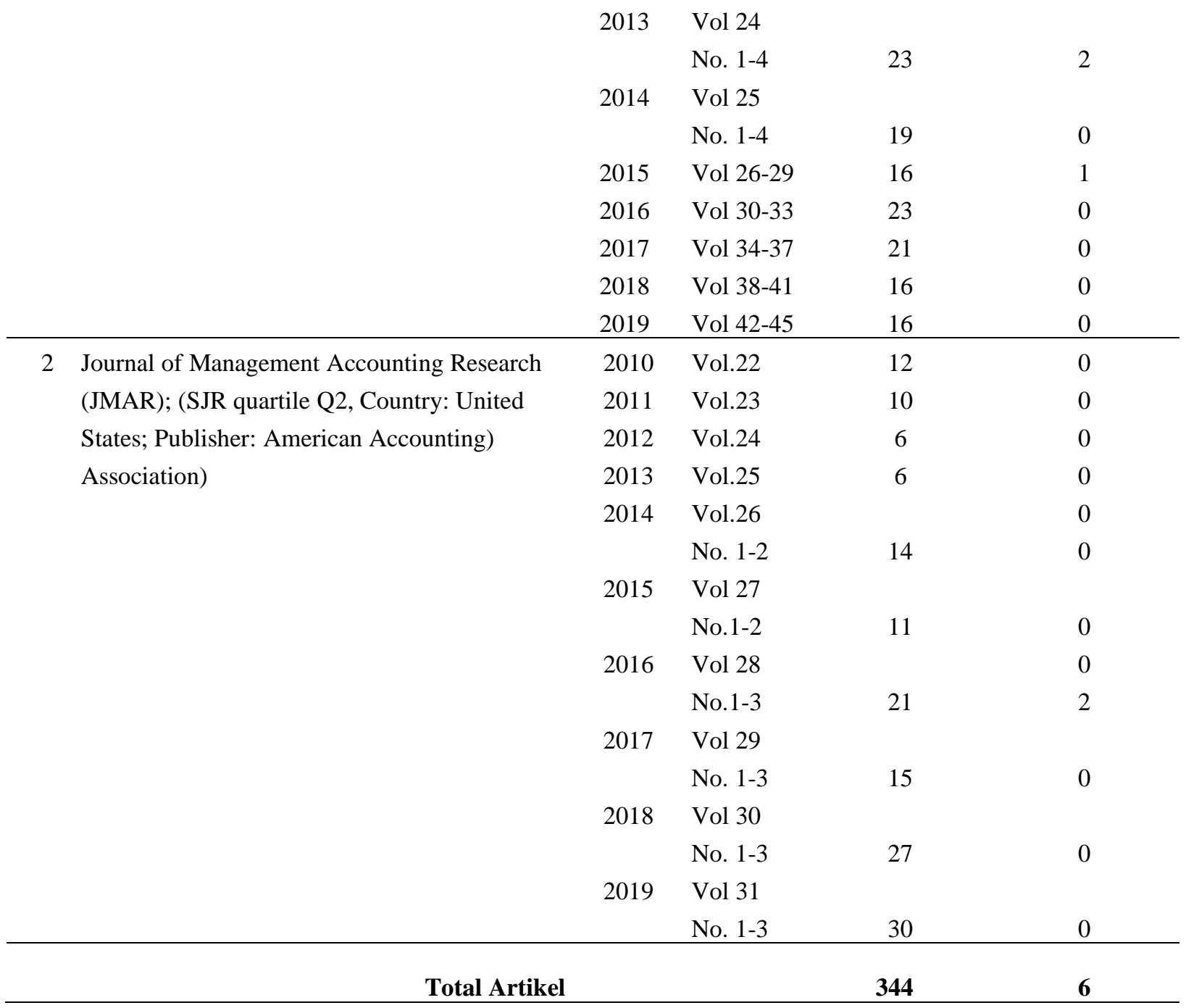

Tabel 1 menunjukkan total 344 artikel yang diterbitkan selama periode 2010-2019 oleh Management Accounting Research (192 artikel) dan Journal of Management Accounting Research (152 artikel). Dari 344 artikel, terdapat 6 artikel yang muncul dengan kata kunci 'sustainability' dan 'management control system'.

Table 2. Enam Artikel yang Dianalisis

\begin{tabular}{llll}
\hline Tahun & $\begin{array}{l}\text { Judul } \\
\text { Management Accounting Research }\end{array}$ & Penulis & Keterangan \\
2012 & $\begin{array}{l}\text { Configuring management control systems: } \\
\text { Theorizing the integration of strategy and } \\
\text { sustainability }\end{array}$ & Gond et al & Vol 23(3); hal. 205-223 \\
2013 & $\begin{array}{l}\text { Environmental management control systems: } \\
\text { nondeville et al }\end{array}$ & Vol 24(4); hal. 317-332
\end{tabular}

* Corresponding author's e-mail: cuynit@yahoo.com http://openjournal.unpam.ac.id/index.php/JABI 
Jurnal Akuntansi Berkelanjutan Indonesia - Vol. 4, No. 1, Jan 2021 - SeTin; Setiawan \&

Christy

The role of contextual and strategic factors.

2013 The use of management control systems to manage CSR strategy: A levers of control perspectives.

2015 Translating environmental motivations into performance: The role of environmental performance measurement systems. Journal of Management Accounting Research Sustainability reporting driving forces and

2016 management control systems

Diane-Laure

Vol 24(4); hal. 284-300

Arjaliès; Julia

Mund

Irene Eleonora Lisi $\quad$ Vol 29(5); hal 1-18

Irene $\mathrm{M}$.

Vol 28(2); hal 103-124

Herremans; Jamal

A. Nazari

2016 Exploring sustainability control systems' integration: The relevance of sustainability Angelo Ditillo;

Vol 28(2); hal 125-148 Irene Eleonora Lisi orientation.

Tabel 2 menjelaskan profil 6 artikel yang ditemukan pada periode 2010-2019, yaitu empat artikel dari Management Accounting Research dan dua artikel dari Journal of Management Accounting Research

Artikel 1: Configuring management control systems: Theorizing the integration of strategy and sustainability

Artikel (1) dimotivasi oleh masih sedikitnya informasi tentang bagaimana sistem kontrol manajemen berkontribusi di dalam mengintegrasikan keberlanjutan ke dalam strategi organisasi. Meskipun organisasi telah banyak menganut retorika keberlanjutan dalam wacana dan pelaporan eksternal, akan tetapi informasi tentang integrasi sistem kontrol manajemen ke dalam strategi organisasi masih sangat terbatas. Artikel (1) memberi usulan teori tentang hal ini dengan cara memperluas literatur management control system karya Simon (2006) ke dalam domain keberlanjutan, yaitu dengan menguraikan konsep integrasi management control system dan keberlanjutan dalam proses pembaruan strategis yang berdampak pada triple bottom line.

Artikel (1) menggunakan teori management control system karya Simon (2006), yaitu penggunaan kontrol diagnostik dan penggunaan kontrol interaktif terkait kontribusi pada proses pembuatan strategi. Sistem kontrol diagnostik adalah sistem kontrol yang membantu dalam pencapaian strategi organisasi sedangkan sistem kontrol interaktif adalah sistem kontrol yang masuk dalam pembentukan strategi, memandu strategi yang muncul dalam menanggapi peluang dan / atau ancaman dalam lingkungan organisasi. Untuk tingkat integrasi keberlanjutan ke dalam strategi organisasi, studi ini menggunakan pendekatan konfigurasi oleh Simons (2006) Dimensi integrasi mengacu pada proses sosio-teknis yaitu, mencakup dimensi organisasi, kognitif, dan teknis (Emery \& Trist, 1969)

* Corresponding author's e-mail: cuynit@yahoo.com http://openjournal.unpam.ac.id/index.php/JABI 
Jurnal Akuntansi Berkelanjutan Indonesia - Vol. 4, No. 1, Jan 2021 - SeTin; Setiawan \& Christy

Artikel (1) menghasilkan delapan konfigurasi teori yang menguraikan konsep integrasi management control system dan keberlanjutan dalam proses pembaruan strategis yang berdampak pada triple bottom line. Delapan konfigurasi dibuat berdasarkan berbagai situasi di mana organisasi memiliki sistem kontrol manajemen (MCS) dan sistem kontrol keberlanjutan (SCS). Dari sistem kontrol yang dimiliki perusahaan, apakah menekankan pada sistem diagnostic control ataukah interactive control, sehingga memberi konsekuensi pada stabilitas dan strategi perusahaan, dan pada akhirnya berujung pada kinerja triple bottom line (kinerja lingkungan, sosial, ekonomi) di jangka pendek dan jangka panjang.

Misalnya, salah satu konfigurasi menjelaskan tentang situasi di mana organisasi memiliki sistem kontrol manajemen (MCS) dan sistem kontrol keberlanjutan (SCS) dengan penekanan pada diagnostic control dan tidak membuat interactive control. Sistem control perusahaan tidak dimobilisasi untuk mengerahkan strategi. CEO tidak memiliki visi pengembangan masa depan baik dalam domain strategis maupun domain keberlanjutan; situasi ini membawa pada kondisi stabilitas perusahaan yang rendah. Kurangnya strategi dalam lingkungan yang kompetitif akan memaksa organisasi keluar dari bisnis, dan memberi konsekuensi pada kinerja triple bottom line yang rendah. Artikel (1) adalah kajian teoritis (studi literatur)

Hasil artikel (1) mendukung penelitian di masa depan tentang peran MCS dan SCS dalam integrasi keberlanjutan ke dalam strategi perusahaan. Hasil konfigurasi teori dari interaksi MCS dan SCS juga dapat dikonsolidasikan ke teori lain di masa depan. Beberapa agenda riset mendatang, yaitu pertama, mengidentifikasi faktor lain (misalnya faktor organisasi, kepemimpinan, dan lingkungan) yang mungkin mempengaruhi organisasi meengintegrasikan MCS dan keberlanjutan ke dalam strategi perusahaan; kedua, mengevaluasi secara empiris apakah dan bagaimana organisasi menyeimbangkan perhatian manajerial pada MCS dan SCS; ketiga, mengevaluasi hasil konfigurasi yang paling mungkin bertahan dari sistem kontrol dan strategi keberlanjutan; keempat, menggunakan metode campuran untuk menyelidiki pengaruh konfigurasi pada kinerja keberlanjutan di berbagai organisasi. Riset mendatang juga diharapkan tidak sepenuhnya mendefinisikan kapasitas organisasi hanya dengan keseimbangan triple bottom line, tetapi pada ukuran kinerja keberlanjutan yang lain.

Artikel 2: Environmental management control systems: The role of contextual and strategic factors

Artikel (2) menguji peran faktor kontekstual dan faktor strategis pada pengembangan sistem kontrol manajemen lingkungan (environmental management control systems/ EMCS). Faktor kontekstual mengacu pada peran persepsi ketidakpastian lingkungan ekologis (perceived ecological environmental uncertainty) dan peran persepsi tekanan pemangku kepentingan (perceived stakeholder pressure).

* Corresponding author's e-mail: cuynit@yahoo.com http://openjournal.unpam.ac.id/index.php/JABI 
Jurnal Akuntansi Berkelanjutan Indonesia - Vol. 4, No. 1, Jan 2021 - SeTin; Setiawan \& Christy

Faktor strategis mengacu pada peran tingkat proaktif lingkungan perusahaan (degree of corporate environmental proactivity).

Artikel (2) menggunakan teori sistem kontrol manajemen lingkungan. Sistem kontrol manajemen lingkungan mengacu pada sistem informasi lingkungan (Chenhall \& Morris, 1986). Sistem kontrol manajemen lingkungan formal mengacu pada komponen yang paling terlihat dan objektif dari sistem kontrol, yaitu aturan fitur, standar operasional prosedur dan kontrol hasil (Langfield-Smith, 1997). Sistem kontrol manajemen lingkungan informal mengacu pada partisipasi karyawan.

Perusahaan yang mempersepsikan ketidakpastian lingkungan yang lebih besar (perceive greater ecological environmental uncertainty) cenderung kurang mengembangkan strategi lingkungan yang proaktif, sistem informasi lingkungan atau sistem kontrol manajemen lingkungan yang formal. Tekanan pemangku kepentingan (misalnya pasar, masyarakat, organisasi) berperan meningkatkan pengembangan sistem kontrol manajemen lingkungan, memotivasi proaktif lingkungan dan pengembangan berbagai sistem kontrol manajemen lingkungan.

Penelitian ini menggunakan pendekatan kuantitatif dengan metode survei di 256 perusahaan manufaktur di Belgia. Survei melalui kuesioner disebarkan pada level perusahaan, yaitu pada CEO/ senior manajer dengan jumlah responden sebanyak 283. Analisis data menggunakan teknik Partial Least Square WarpPLS 3.0.

Artikel (2) menyarankan beberapa agenda riset mendatang, yaitu pertama, membahas pengaruh spesifik kelompok pemangku kepentingan yang berbeda dan interaksinya pada pengembangan proaktif lingkungan dan sistem kontrol manajemen lingkungan; kedua, menguji karakteristik lain dari sistem informasi lingkungan, seperti penggunaan informasi lingkungan kuantitatif versus kualitatif dan ketepatan waktu sistem informasi lingkungan; ketiga, menguji konsekuensi pengembangan EMCS yang dihubungkan dengan ukuran kinerja lingkungan.

Artikel 3: The use of management control systems to manage CSR strategy: A levers of control perspectives

Artikel (3) dimotivasi oleh masih sedikitnya informasi tentang peran sistem pengendalian manajemen di dalam mengelola strategi yang mendukung tanggung jawab sosial perusahaan. Tujuan studi adalah memberikan gambaran tentang bagaimana organisasi menggunakan sistem pengendalian manajemen untuk mendorong pembaruan strategis, memicu perubahan organisasi dan sekaligus mendukung agenda keberlanjutan yang lebih luas. Artikel (3) memberikan wawasan tentang struktur dan proses yang digunakan perusahaan untuk merancang, mengimplementasikan dan memantau strategi CSR.

Artikel (3) menggunakan kerangka four levers of control dari Simons (1995), yaitu keyakinan (beliefs), batasan (boundaries), diagnostik (diagnostic) dan interaktif (interactive) untuk menganalisis bagaimana organisasi memanfaatkan sistem pengendalian manajemen guna menerapkan strategi bisnis. Terkait strategi CSR

* Corresponding author's e-mail: cuynit@yahoo.com http://openjournal.unpam.ac.id/index.php/JABI 
Jurnal Akuntansi Berkelanjutan Indonesia - Vol. 4, No. 1, Jan 2021 - SeTin; Setiawan \& Christy

mengacu pada bagaimana pelaporan CSR digunakan untuk mengelola ketidakpastian strategis.

Artikel (3) memberi bukti cara organisasi mencapai tujuan tanggungjawab sosial, dan hubungan antara manajemen tanggungjawab sosial dan proses bisnis lainnya. Kerangka four levers of control dari Simons (1995), berperan bagi manajer untuk mengidentifikasi dan mengelola ancaman dan peluang yang terkait dengan strategi tanggungjawab sosial, sehingga membentuk proses manajemen risiko yang mendukung organisasi dalam mencapai tujuan strategis. Studi ini juga memberikan bukti bahwa penggunaan sistem pengendalian manajemen berkontribusi pada agenda keberlanjutan melalui proses yang memungkinkan inovasi, komunikasi, pelaporan, dan identifikasi ancaman dan peluang.

Artikel (3) menggunakan pendekatan content analysis. Data dikumpulkan dengan metode survei, bukti dokumen dan pemeringkatan sosial (social ratings) di 36 perusahaan di Prancis. Survei melalui kuesioner disebarkan pada level manajerial, yaitu pada 27 kepala departemen tanggung jawab sosial. Data were translated by one of the reserchers.

Artikel (3) terbatas dalam desain penelitian, yaitu data penggunaan sistem pengendalian manajemen hanya berasal dari satu responden yang secara langsung terkait dengan strategi tanggungjawab sosial di perusahaannya, sehingga studi ini mengecualikan pandangan individu lain serta proses informal yang mungkin berdampak pada pengelolaan strategi tanggungjawab sosial. Riset mendatang disarankan mempertimbangkan sampel yang lebih luas dan mempertimbangkan proses informal di dalam menganalisis pengelolaan strategis tanggungjawab sosial.

Artikel 4 : Translating environmental motivations into performance: The role of environmental performance measurement systems

Artikel (4) dimotivasi oleh masih sedikitnya informasi tentang environmentalisme korporat (corporate environmentalism) terkait proses manajerial di dalam menterjemahkan faktor motivasi menjadi peningkatan kinerja lingkungan. Untuk menguji peran pengukuran kinerja dalam konteks lingkungan, artikel ini menguji model, yaitu peran mediasi penggunaan ukuran kinerja lingkungan (environmental performance measurement systems-EPM Use) untuk berbagai tujuan pengambilan keputusan dan kontrol di dalam hubungan antara motivasi lingkungan perusahaan (environmental motivations) dan kinerja perusahaan (corporate performance).

Artikel (4) menggunakan teori dari literatur akuntansi lingkungan yaitu sistem pengukuran kinerja lingkungan (environmental performance measurement systems EPM Use). EPM-Use mengacu pada ukuran berdasarkan Global Reporting Initiatives (GRI-3), yang mencakup kinerja terkait input (bahan, energi, air), output (emisi, limbah, limbah), keanekaragaman hayati, kepatuhan lingkungan, dan informasi

* Corresponding author's e-mail: cuynit@yahoo.com http://openjournal.unpam.ac.id/index.php/JABI 
Jurnal Akuntansi Berkelanjutan Indonesia - Vol. 4, No. 1, Jan 2021 - SeTin; Setiawan \& Christy

lainnya, misalnya pengeluaran lingkungan dan dampak produk dan layanan (GRI, 2006).

Artikel (4) menunjukkan hasil yaitu, pertama, penggunaan pengukuran kinerja lingkungan (EPM use) untuk pengambilan keputusan dan kontrol secara positif dipengaruhi oleh keunggulan kompetitif yang diharapkan (expected competitive advantage), persepsi kepedulian pemangku kepentingan (perceived stakeholders' concern) dan komitmen lingkungan manajemen puncak (top management's environmental commitment). Kedua, kinerja lingkungan (environmental performance) dipengaruhi secara positif oleh penggunaan EPM untuk pengambilan keputusan dan kontrol (EPM use for decision-making and control); Ketiga, kinerja ekonomi (economic performance) secara positif dipengaruhi oleh penggunaan EPM untuk pengambilan keputusan dan kontrol melalui kinerja lingkungan (EPM use for decision-making and control).

Artikel (4) menggunakan pendekatan kuantitatif (pengujian hipotesis) dengan metode survei (web based questionnaire) di perusahaan Italia yang memiliki karyawan di atas 100. Survei dilakukan pada level manajerial, yaitu kepada 443 CSR manajer, dan diperoleh 91 responden yang dapat dianalisis. Analisis data menggunakan teknik Partial least square structural equation modelling.

Penggunaan EPM (EPM use) merujuk pada item konteks lingkungan dari Ittner \& Larcker (2001), Parego \& Hartmann (2009) dan Gerdin (2005). Skala kinerja lingkungan (environmental performance) dikembangkan oleh Hakim \& Doughlas, 1998. Kinerja keuangan/ ekonomi (diukur dengan pengembalian atas modal yang digunakan (return on capital employed /ROCE).

Artikel (4) merekomendasikan riset mendatang, yaitu pertama, menguji hubungan antara persepsi kepedulian pemangku kepentingan (perceived stakeholders' concern) dan penggunaan EPM (EPM Use); kedua, menginvestigasi dimensi sosial dari konsep keberlanjutan dan menyelidiki peran sistem pengukuran kinerja sosial (role of social performance measurement systems); ketiga, memperbaiki dan memvalidasi instrumen penggunaan EPM untuk tujuan pengambilan keputusan dan kontrol (EPM Use).

Artikel 5: Sustainability reporting driving forces and management control systems

Artikel (5) menyelidiki bagaimana tekanan eksternal (external pressures) memunculkan beragam sistem dan proses kontrol pelaporan keberlanjutan. Artikel (5) menjelaskan bagaimana sistem kontrol pelaporan keberlanjutan formal dan informal (formal and informal sustainability reporting control systems) dikembangkan sesuai dengan tekanan eksternal yaitu motivasi manajerial (managerial motivations) dan jenis hubungan pemangku kepentingan (types of stakeholder relationships).

Artikel (5) menggunakan teori kelembagaan (institutional theory) menurut Aupperle et al., 1985. Teori ini merujuk pada bagaimana respon organisasi serupa atau isomorfik. Kelembagaan Logika (Thornton \& Ocasio, 2008) merujuk pada

* Corresponding author's e-mail: cuynit@yahoo.com http://openjournal.unpam.ac.id/index.php/JABI 
Jurnal Akuntansi Berkelanjutan Indonesia - Vol. 4, No. 1, Jan 2021 - SeTin; Setiawan \& Christy

bagaimana tanggapan berbeda ketika ada logika bersaing secara bersamaan. Teori sistem kontrol dari Simons 1995 juga digunakan, yaitu sistem kontrol mekanistik formal mengacu pada sistem diagnostik versus kontrol mekanistik informal mengacu pada sistem kontrol organik.

Artikel (5) menemukan bahwa jenis hubungan pemangku kepentingan dan keseimbangan antara sistem kontrol formal dan informal mempengaruhi karakteristik pelaporan keberlanjutan yang dikembangkan perusahaan. Jenis sistem kontrol pelaporan keberlanjutan bergantung pada motivasi dan sikap manajerial ketika mereka merespon tekanan eksternal. Temuan memberikan wawasan tentang bagaimana sistem kontrol pelaporan keberlanjutan formal dan informal dikembangkan sesuai dengan motivasi manajerial dan jenis hubungan pemangku kepentingan. Jenis dan keseimbangan antara sistem kontrol formal dan informal mempengaruhi karakteristik pelaporan keberlanjutan.

Artikel (5) menggunakan pendekatan studi kasus (primarily qualitative case study) dengan jenis data adalah data primer dan data arsip terkait operasi perusahaan, struktur pengelolaan dan hasil pelaporan. Artikel (5) mengumpulkan data dengan metode wawancara dengan perusahaan dan pemangku kepentingan serta observasi pada sampel perusahaan Kanada di industri minyak dan gas. Wawancara dilakukan pada 11 karyawan di level manajerial. Analisis data hasil wawancara menggunakan teknik integrated archival data.

Artikel (5) terbatas pada satu industri sehingga generalisasi terbatas. Beberapa saran untuk studi mendatang, yaitu pertama, menggunakan lebih banyak sampel di industri yang berbeda dan mempersempit ruang lingkup penelitian dengan mengidentifikasi bagaimana kelompok pemangku kepentingan tertentu mempengaruhi kinerja keberlanjutan dan proses pelaporan; kedua, mengembangkan jenis dan keseimbangan sistem kontrol formal and informal yang mempengaruhi karakteristik pelaporan keberlanjutan.

Beberapa pertanyaan untuk penelitian masa depan, yaitu pertama, bagaimana proses identifikasi risiko mempengaruhi alokasi sumber daya untuk mengurangi risiko dan apakah jika persepsi perusahaan tentang area berisiko tinggi, adalah sama dengan persepsi pemangku kepentingan? kedua, bagaimana proses ini mempengaruhi sistem dan kontrol manajemen yang dikembangkan secara internal untuk mengelola risiko dan apa yang dilaporkan? Ketiga, studi saat ini mengamati perubahan dalam perusahaan yang awalnya termotivasi oleh mandat asosiasi industri yang secara sukarela menghasilkan laporan yang tersedia di situs web. Penelitian di masa depan dapat menentukan bagaimana dan mengapa perubahan ini terjadi.

Artikel 6: Exploring sustainability control systems' integration: The relevance of sustainability orientation

Artikel (6) dilatarbelakangi oleh masih sedikit informasi tentang kontrol manajemen untuk keberlanjutan (management control for sustainability). Artikel ini

* Corresponding author's e-mail: cuynit@yahoo.com

http://openjournal.unpam.ac.id/index.php/JABI 
menyelidiki bagaimana integrasi antara sistem kontrol keberlanjutan dengan sistem kontrol manajemen yang lebih tradisional dipengaruhi oleh orientasi keberlanjutan manajerial (managerial sustainability orientation). Studi ini memberikan wawasan tentang kompleksitas dan konsekuensi disfungsional yang potensial (potential dysfunctional consequences) dari proses integrasi.

Artikel (6) menggunakan teori tiga dimensi orientasi keberlanjutan manajerial (managerial sustainability orientation), yaitu pertama, permintaan utama pengakuan manajerial atas tanggung jawab sosial dan lingkungan, yang dapat bersifat sukarela dalam mempromosikan inisiatif keberlanjutan atau responsif terhadap tekanan sosial eksternal (O'Dwyer 2003). Kedua, Semakin tinggi / rendahnya kekuatan dorongan manajemen untuk membuat organisasi menjadi pemimpin di arena keberlanjutan (Wood \& Robertson 1997); ketiga, Niat manajerial untuk memasukkan aspek keberlanjutan ke dalam model bisnis organisasi (Yuan et al., 2011).

Fokus pada dimensi teknis integrasi (Emery \& Trist, 1969).

Integrasi MCS dan SCS melibatkan hubungan metodologis antara dua jenis sistem (keberadaan infrastruktur umum untuk mengumpulkan, memproses, dan mewakili informasi untuk kedua sistem dan penggabungan target dan indikator keberlanjutan ke dalam penganggaran tradisional dan mengelola sistem pelaporan perusahaan)

Sifat orientasi keberlanjutan perusahaan (nature of a firm's sustainability orientation) merupakan pemicu utama dalam menjelaskan variasi dalam integrasi SCS, dan integrasi ini difasilitasi oleh calon pemungkin (potential enablers) lainnya yang menciptakan lingkungan positif yang mendukung inisiatif keberlanjutan (sustainability initiatives).

Artikel (6) menggunakan pendekatan studi kasus (primarily qualitative case study) dengan jenis data adalah data primer dan data arsip terkait operasi perusahaan, struktur pengelolaan dan hasil pelaporan. Artikel (6) mengumpulkan data dengan metode wawancara pada level manajerial, observasi dan dokumen arsip. Sampel adalah 4 perusahaan di Italia. Wawancara dilakukan pada level manajerial yaitu 4 manajer keberlanjutan. Analisis data hasil wawancara menggunakan teknik integrated archival data.

Artikel (6) baru membahas permukaan kompleksitas mekanisme kontrol untuk keberlanjutan. Studi mendatang disarankan untuk pertama, mengklasifikasi, menggambarkan dimensi SCS dan memperbanyak variabel yang mempengaruhi konfigurasi SCS dan efektivitasnya dalam mengarahkan perilaku bisnis; kedua, menyelidiki bagaimana proses merancang SCS dan memadukannya dengan MCS yang lebih tradisional.

Table 3. Ringkasan Hasil Studi

Artikel 1

Artikel 2

Artikel 3

Artikel 4

Artikel 5

Artikel 6

* Corresponding author's e-mail: cuynit@yahoo.com http://openjournal.unpam.ac.id/index.php/JABI 


\begin{tabular}{|c|c|c|c|c|c|c|}
\hline Tujuan & $\begin{array}{l}\text { Menjelaskan } \\
\text { bagaimana } \\
\text { sistem } \\
\text { kontrol } \\
\text { manajemen } \\
\text { berkontribusi } \\
\text { mengintegra } \\
\text { si } \\
\text { keberlanjuta } \\
\text { n ke dalam } \\
\text { strategi } \\
\text { organisasi. }\end{array}$ & $\begin{array}{l}\text { Menguji peran } \\
\text { faktor } \\
\text { kontekstual dan } \\
\text { faktor strategis } \\
\text { pada } \\
\text { pengembangan } \\
\text { sistem kontrol } \\
\text { manajemen } \\
\text { lingkungan }\end{array}$ & $\begin{array}{l}\text { Menjelaskan } \\
\text { bagaimana } \\
\text { organisasi } \\
\text { menggunaka } \\
\mathrm{n} \text { sistem } \\
\text { pengendalia } \\
\mathrm{n} \\
\text { manajemen } \\
\text { untuk } \\
\text { mendorong } \\
\text { pembaruan } \\
\text { strategis, } \\
\text { memicu } \\
\text { perubahan } \\
\text { organisasi } \\
\text { dan } \\
\text { mendukung } \\
\text { agenda } \\
\text { keberlanjuta } \\
\mathrm{n}\end{array}$ & $\begin{array}{l}\text { Menguji } \\
\text { peran } \\
\text { pengukuran } \\
\text { kinerja dalam } \\
\text { konteks } \\
\text { lingkungan, } \\
\text { menguji } \\
\text { peran } \\
\text { mediasi } \\
\text { ukuran } \\
\text { kinerja } \\
\text { lingkungan } \\
\text { pada } \\
\text { hubungan } \\
\text { antara } \\
\text { motivasi } \\
\text { lingkungan } \\
\text { perusahaaan } \\
\text { dan kinerja } \\
\text { perusahaan }\end{array}$ & $\begin{array}{l}\text { Menyelidiki } \\
\text { bagaimana } \\
\text { tekanan } \\
\text { eksternal } \\
\text { memunculka } \\
\text { n beragam } \\
\text { sistem dan } \\
\text { proses } \\
\text { kontrol } \\
\text { pelaporan } \\
\text { keberlanjutan }\end{array}$ & $\begin{array}{l}\text { Menyelidiki } \\
\text { bagaimana } \\
\text { integrasi } \\
\text { antara sistem } \\
\text { kontrol } \\
\text { keberlanjutan } \\
\text { dengan sistem } \\
\text { kontrol } \\
\text { manajemen } \\
\text { yang lebih } \\
\text { tradisional } \\
\text { dipengaruhi } \\
\text { oleh orientasi } \\
\text { keberlanjutan } \\
\text { manajerial }\end{array}$ \\
\hline $\begin{array}{l}\text { Teori yang } \\
\text { digunakan }\end{array}$ & $\begin{array}{l}\text { Management } \\
\text { Control } \\
\text { System, } \\
\text { karya Simon, } \\
2006\end{array}$ & $\begin{array}{l}\text { Sistem Kontrol } \\
\text { Manajemen } \\
\text { Lingkungan }\end{array}$ & $\begin{array}{l}\text { Four Levers } \\
\text { of Control } \\
\text { dari Simon, } \\
1995\end{array}$ & $\begin{array}{l}\text { Environment } \\
\text { al } \\
\text { performance } \\
\text { management } \\
\text { system (EPM } \\
\text { Use) }\end{array}$ & $\begin{array}{l}\text { Teori } \\
\text { Kelembagaan } \\
\text { (Institutional } \\
\text { theory) }\end{array}$ & $\begin{array}{l}\text { Teori } \\
\text { managerial } \\
\text { sustainability } \\
\text { orientation } \\
\text { (O’Downer, } \\
\text { 2003) } \\
\end{array}$ \\
\hline Hasil Studi & $\begin{array}{l}\text { Delapan } \\
\text { konfigurasi } \\
\text { teori } \\
\text { (konsep } \\
\text { integrasi } \\
\text { management } \\
\text { control } \\
\text { system dan } \\
\text { keberlanjuta } \\
\text { n yang } \\
\text { berdampak } \\
\text { pada triple } \\
\text { bottom line). }\end{array}$ & $\begin{array}{l}\text { Perusahaan } \\
\text { yang } \\
\text { mempersepsika } \\
\text { n } \\
\text { ketidakpastian } \\
\text { lingkungan } \\
\text { yang lebih } \\
\text { besar kurang } \\
\text { mengembangka } \\
\text { n strategi } \\
\text { lingkungan } \\
\text { yang proaktif. } \\
\text { Tekanan } \\
\text { stakeholders } \\
\text { berperan } \\
\text { meningkatkan } \\
\text { pengembangan } \\
\text { sistem kontrol } \\
\text { manajemen } \\
\text { lingkungan, } \\
\text { memotivasi } \\
\text { proaktif } \\
\text { lingkungan. }\end{array}$ & $\begin{array}{l}\text { Penggunaan } \\
\text { sistem } \\
\text { pengendalia } \\
\text { n } \\
\text { manajemen } \\
\text { berkontribus } \\
\text { i pada } \\
\text { agenda } \\
\text { keberlanjuta } \\
\text { n melalui } \\
\text { proses } \\
\text { inovasi, } \\
\text { komunikasi, } \\
\text { pelaporan, } \\
\text { dan } \\
\text { identifikasi } \\
\text { ancaman dan } \\
\text { peluang. }\end{array}$ & $\begin{array}{l}\text { Pengukuran } \\
\text { kinerja } \\
\text { lingkungan } \\
\text { secara positif } \\
\text { dipengaruhi } \\
\text { oleh } \\
\text { keunggulan } \\
\text { kompetitif, } \\
\text { Persepsi } \\
\text { kepedulian } \\
\text { stakeholders } \\
\text { dan } \\
\text { komitmen } \\
\text { lingkungan } \\
\text { manajemen } \\
\text { puncak; } \\
\text { Kedua, } \\
\text { kinerja } \\
\text { lingkungan } \\
\text { dipengaruhi } \\
\text { secara positif } \\
\text { oleh } \\
\text { penggunaan } \\
\text { EPM; kinerja } \\
\text { ekonomi } \\
\text { secara positif } \\
\text { dipengaruhi } \\
\text { penggunaan }\end{array}$ & $\begin{array}{l}\text { Jenis } \\
\text { hubungan } \\
\text { stakeholders } \\
\text { dan } \\
\text { keseimbanga } \\
\text { n antara } \\
\text { sistem } \\
\text { kontrol } \\
\text { formal dan } \\
\text { informal } \\
\text { mempengaru } \\
\text { hi } \\
\text { karakteristik } \\
\text { pelaporan } \\
\text { keberlanjutan } \\
\text { yang } \\
\text { dikembangka } \\
\text { n perusahaan. }\end{array}$ & $\begin{array}{l}\text { Sifat orientasi } \\
\text { keberlanjutan } \\
\text { perusahaan } \\
\text { merupakan } \\
\text { pemicu utama } \\
\text { dalam } \\
\text { menjelaskan } \\
\text { variasi dalam } \\
\text { integrasi SCS, } \\
\text { dan integrasi } \\
\text { ini difasilitasi } \\
\text { oleh potential } \\
\text { enablers } \\
\text { lainnya yang } \\
\text { menciptakan } \\
\text { lingkungan } \\
\text { positif yang } \\
\text { mendukung } \\
\text { inisiatif } \\
\text { keberlanjutan }\end{array}$ \\
\hline
\end{tabular}

* Corresponding author's e-mail: cuynit@yahoo.com http://openjournal.unpam.ac.id/index.php/JABI 


\begin{tabular}{|c|c|c|c|c|c|c|}
\hline Metodologi & $\begin{array}{l}\text { Kajian } \\
\text { teoretis } \\
\text { (studi } \\
\text { literatur) }\end{array}$ & $\begin{array}{l}\text { Pengujian } \\
\text { hipotesis } \\
\text { dengan metode } \\
\text { survei }\end{array}$ & $\begin{array}{l}\text { content } \\
\text { analysis. } \\
\text { metode } \\
\text { survei }\end{array}$ & $\begin{array}{l}\text { Pengujian } \\
\text { hipotesis } \\
\text { dengan } \\
\text { metode } \\
\text { survei } \\
\end{array}$ & $\begin{array}{l}\text { Studi kasus } \\
\text { Wawancara }\end{array}$ & $\begin{array}{l}\text { Studi kasus } \\
\text { Wawancara }\end{array}$ \\
\hline $\begin{array}{l}\text { Agenda/ } \\
\text { Saran Riset } \\
\text { Mendatang }\end{array}$ & $\begin{array}{l}\text { Mendefinisi } \\
\text { kan kapasitas } \\
\text { organisasi } \\
\text { tidak hanya } \\
\text { dengan } \\
\text { keseimbanga } \\
\text { n triple } \\
\text { bottom line, } \\
\text { tetapi pada } \\
\text { ukuran } \\
\text { kinerja } \\
\text { keberlanjuta } \\
\text { n yang lain. }\end{array}$ & $\begin{array}{l}\text { Membahas } \\
\text { pengaruh } \\
\text { spesifik } \\
\text { kelompok } \\
\text { stakeholders } \\
\text { yang berbeda } \\
\text { dan } \\
\text { interaksinya } \\
\text { pada } \\
\text { pengembangan } \\
\text { proaktif } \\
\text { lingkungan dan } \\
\text { sistem kontrol } \\
\text { manajemen } \\
\text { lingkungan; } \\
\text { Menguji } \\
\text { karakteristik } \\
\text { lain dari sistem } \\
\text { informasi } \\
\text { lingkungan, } \\
\text { dan } \\
\text { konsekuensi } \\
\text { pengembangan } \\
\text { EMCS yang } \\
\text { dihubungkan } \\
\text { dengan ukuran } \\
\text { kinerja } \\
\text { lingkungan }\end{array}$ & $\begin{array}{l}\text { Sampel yang } \\
\text { lebih luas } \\
\text { dan } \\
\text { mempertim- } \\
\text { bangkan } \\
\text { proses } \\
\text { informal di } \\
\text { dalam } \\
\text { menganalisis } \\
\text { pengelolaan } \\
\text { strategis } \\
\text { tanggung } \\
\text { jawab sosial. }\end{array}$ & $\begin{array}{l}\text { Menguji } \\
\text { hubungan } \\
\text { persepsi } \\
\text { kepedulian } \\
\text { stakeholders } \\
\text { dan } \\
\text { penggunaan } \\
\text { EPM; } \\
\text { Investigasi } \\
\text { dimensi } \\
\text { sosial dari } \\
\text { konsep } \\
\text { keberlanjutan } \\
\text { dan } \\
\text { menyelidiki } \\
\text { peran sistem } \\
\text { pengukuran } \\
\text { kinerja sosial, } \\
\text { memperbaiki } \\
\text { dan } \\
\text { memvalidasi } \\
\text { instrumen } \\
\text { penggunaan } \\
\text { EPM untuk } \\
\text { pengambilan } \\
\text { keputusan } \\
\text { dan kontrol }\end{array}$ & $\begin{array}{l}\text { Perbanyak } \\
\text { sampel di } \\
\text { industri yang } \\
\text { berbeda; } \\
\text { persempit } \\
\text { lingkup riset } \\
\text { dengan } \\
\text { identifikasi } \\
\text { bagaimana } \\
\text { stakeholders } \\
\text { mempengaru } \\
\text { hi kinerja } \\
\text { keberlanjutan } \\
\text { dan proses } \\
\text { pelaporan; } \\
\text { Kembangkan } \\
\text { jenis dan } \\
\text { keseimbanga } \\
\text { n sistem } \\
\text { kontrol } \\
\text { formal/ } \\
\text { informal } \\
\text { yang } \\
\text { mempengaru } \\
\text { hi } \\
\text { karakteristik } \\
\text { pelaporan } \\
\text { keberlanjutan }\end{array}$ & $\begin{array}{l}\text { Memperbanya } \\
\text { k variabel } \\
\text { yang } \\
\text { mempengaruh } \\
\text { i konfigurasi } \\
\text { SCS dan } \\
\text { efektivitasnya } \\
\text { dalam } \\
\text { mengarahkan } \\
\text { perilaku } \\
\text { bisnis; } \\
\text { Menyelidiki } \\
\text { bagaimana } \\
\text { proses } \\
\text { merancang } \\
\text { SCS dan } \\
\text { memadukan } \\
\text { dengan MCS } \\
\text { yang lebih } \\
\text { tradisional. }\end{array}$ \\
\hline
\end{tabular}

Dari enam artikel yang diuraikan di dalam artikel ini, terdapat empat artikel yang khusus memeriksa sistem kontrol keberlanjutan dan dua artikel yang memeriksa 
integrasi antara sistem kontrol manajemen dan sistem kontrol keberlanjutan. Artikel yang memeriksa sistem kontrol keberlanjutan fokus pada kelestarian lingkungan dan membahas peran sistem kontrol manajemen di dalam mengelola strategi tanggungjawab sosial dan hubungan antara tekanan eksternal dengan sistem kontrol keberlanjutan. Keempat artikel ini menambah beberapa penelitian sebelumnya yang fokus pada keberlanjutan lingkungan, dengan sedikit memperhatikan interaksi dengan sistem kontrol manajemen, misalnya penelitian penganggaran lingkungan (Buritt \& Schaltegger, 2001; Roth, 2008); sistem akuntansi biaya material dan aliran energi (Jasch 2009); eco-control (Henry \& Journeault, 2010).

Dua artikel yang memeriksa interaksi antara sistem kontrol keberlanjutan dan sistem kontrol manajemen yang tradisional sejalan dengan Buhr \& Gray, 2012, yang mengemukakan bahwa jika sistem kontrol manajemen dan sistem kontrol keberlanjutan berintegrasi, maka kedua sistem ini dapat bekerjasama dalam harmoni. Untuk kontrol keberlanjutan pada dimensi sosial, walaupun kebutuhan memeriksa kerangka keberlanjutan dalam dimensi ini meningkat (Crutzen \& Herzig, 2013), akan tetapi hanya satu penelitian yang ditemukan dalam analisis ini yang mencakup dimensi sosial keberlanjutan.

Dari enam artikel yang ditemukan, terdapat beberapa teori, kerangka kerja dan pendekatan konseptual yang digunakan di dalam penelitian pengendalian manajemen berkelanjutan, yaitu teori konfigurasi, teori kelembagaan, logika kelembagaan, lever of control dari Simon, sistem kontrol manajemen lingkungan, kinerja lingkungan dan orientasi keberlanjutan. Teori yang digunakan memberi wawasan baru bagi praktik akuntansi manajemen. Tidak adanya perspektif teori yang mendominasi dalam riset kontrol manajemen berkelanjutan mencerminkan adanya beragam perspektif teoretis dan mendorong inovasi teori dalam riset kontrol manajemen keberlanjutan khususnya dan riset akuntansi manajemen pada umumnya.

Walaupun hanya ditemukan 6 artikel, namun jenis penelitian yang digunakan cukup bervariasi, yaitu dua artikel menggunakan metode kuantitatif (menguji hipotesis); dua artikel menggunakan metode kualitatif (studi kasus); dan dua lainnya adalah content analysis. Studi ini juga menemukan bahwa mayoritas artikel melakukan analisis di tingkat manajerial, sedangkan analisis di tingkat organisasi / perusahaan hanya ditemukan satu artikel. Tidak ada analisis yang dilakukan pada tingkat non-manajemen, unit bisnis dan tingkat departemen. Penelitian umumnya menggunakan berbagai jenis data dan berbagai metode pengumpulan data. Jenis data yang digunakan adalah data primer dan data sekunder. Data primer diperoleh melalui survei, wawancara dan observasi, sedangkan data sekunder diperoleh dari data arsip (operasi perusahaan, struktur tata kelola dan hasil pelaporan) dan diperoleh dari bukti dokumenter. Perusahaan yang menjadi sampel penelitian adalah perusahaan di kawasan Eropa, yaitu Belgia, Prancis, Italia dan di kawasan Amerika, yaitu Kanada. Tidak ditemukan studi yang dilakukan di benua Asia, Afrika dan Australia.

* Corresponding author's e-mail: cuynit@yahoo.com http://openjournal.unpam.ac.id/index.php/JABI 


\section{KESIMPULAN DAN SARAN}

Tulisan ini mengulas penelitian di bidang akuntansi manajemen khususnya topik sistem kontrol manajemen untuk keberlanjutan. Beberapa temuan yaitu, pertama, riset memeriksa sistem kontrol keberlanjutan dan memeriksa integrasi antara sistem kontrol manajemen dan sistem kontrol keberlanjutan. Riset sistem kontrol keberlanjutan fokus pada kelestarian lingkungan dan membahas peran sistem kontrol manajemen di dalam mengelola strategi tanggungjawab sosial dan hubungan antara tekanan eksternal dengan sistem kontrol keberlanjutan. Kedua, teori yang digunakan adalah teori konfigurasi, teori kelembagaan, logika kelembagaan, kerangka kerja empat tuas kontrol, sistem kontrol manajemen lingkungan; ketiga, tidak ada yang dominan untuk tipe penelitian, yaitu metode kuantitatif dan kualitatif, analisis teoritis dan konten digunakan di dalam penelitian; keempat, umumnya studi melakukan analisis di tingkat manajerial; kelima, data primer diperoleh melalui survei, wawancara dan observasi, sedangkan data sekunder diperoleh dari data kearsipan.

Peneliti sebelumnya memberikan beberapa agenda riset mendatang, yaitu mendorong penggunaan beragam teori dan metode penelitian untuk mempelajari kinerja keberlanjutan; mengggali ukuran keberlanjutan; memperluas sampel dan mempelajari bagaimana pemangku kepentingan berinteraksi pada sistem kontrol keberlanjutan.

Penelitian ini berusaha melihat perkembangan penelitian pengendalian manajemen keberlanjutan selama sepuluh tahun terakhir pada jurnal yang khusus menerbitkan topik akuntansi manajemen. Pembatasan ini menimbulkan konsekuensi bahwa ada kemungkinan penelitian pengendalian manajemen keberlanjutan yang diterbitkan melalui sumber lain. Keterbatasan ini mungkin mempengaruhi kelengkapan deskripsi perkembangan penelitian kontrol manajemen keberlanjutan. Oleh karena itu, studi selanjutnya disarankan untuk melakukan penelusuran lebih lanjut terkait riset topik kontrol manajemen keberlanjutan pada jurnal internasional terkemuka lainnya untuk mendapatkan lebih banyak referensi sebagai acuan penelitian masa depan.

\section{DAFTAR PUSTAKA}

Adams, C.A., McNicholas, P., (2007). Making a difference - sustainability reporting, accountability and organisational change. Accounting, Auditing \& Accountability Journal 20, 382-402.

* Corresponding author's e-mail: cuynit@yahoo.com http://openjournal.unpam.ac.id/index.php/JABI 
Jurnal Akuntansi Berkelanjutan Indonesia - Vol. 4, No. 1, Jan 2021 - SeTin; Setiawan \& Christy

Aupperle, K. E., A. B. Canoll, and J. D. Hatfield. (1985). An empirical examination of the relationship between corporate social responsibility and profitability. Academy of Management Journal 28(2): 446-463.

Ball, A., Milne, M. (2005). Sustainability and Management Contro. Project: Sustainability: Discourse and Narratives of Business and its Antagonists. Chapter 9, 314-337.

Bartolomeo, M., Bennett, M., Bouma, J.J., Heydkamp, P., James, P., Wolters, T., (2000). Environmental management accounting in Europe: current practice and future potential. European Accounting Review 9, 31-52.

Bonacchi, M., Rinaldi, L., (2007). DartBoards and clovers as new tools in sustainability planning and control. Business Strategy and the Environment 16(7), 461-473.

Burritt, R.L., Herzig, C., Tadeo, B., (2009). Environmental management accounting for cleaner production: the case of a Philippine rice mill. Journal of Cleaner Production 17(4), 431-439

Burritt, R.L., Schaltegger, S., (2010). Sustainability accounting and reporting: fad or trend? Accounting, Auditing \& Accountability Journal 23(7), 829-846.

Byrch, C., Kearins, K., Milne, M., Morgan, R., (2007). Sustainable "what"? A cognitive approach to understanding sustainable development. Qualitative Research in Accounting \& Management 4, 26-52.

Chenhall, R.H., Morris, D., (1986). The impact of structure, environment, and interdependence on the perceived usefulness of management accounting systems. Accounting Review 61 (1), 16-35

Cresti, E., (2009). Sustainability Management Control Systems. Towards a Socially Responsible Planning and Control Framework. Oxford Business \& Economics Conference Program June 24-26, 2009; St. Hugh's College, Oxford University, Oxford, UK

Dias-Sardinha, I., Reijnders, L., Antunes, P., (2002). From environmental performance evaluation to eco-efficiency and sustainability balanced scorecards. Environmental Quality Management 12(2), 51-64.

Epstein, M. J., \& Roy, M.-J. (2001). Sustainability in Action: Identifying and Measuring the Key Performance Drivers. Long Range Planning, 34(5), 585-604.

Elkington, J. (1997). Cannibals with forks - Triple bottom line of 21st century business. Stoney Creek, CT: New Society Publishers.

* Corresponding author's e-mail: cuynit@yahoo.com http://openjournal.unpam.ac.id/index.php/JABI 
Jurnal Akuntansi Berkelanjutan Indonesia - Vol. 4, No. 1, Jan 2021 - SeTin; Setiawan \& Christy

Durden, C. (2008). Towards a socially responsible management control system. Accounting, Auditing \& Accountability Journal 21 (5), 671-694.

Dutta, S.K., Lawson, R.A. (2009). Aligning performance evaluation and reward systems with corporate sustainability goals. Cost Management (November/December), 15-23.

Emery, F.E., Trist, E.L. (1969). Socio-technical systems. In: Emery, F.E. (Ed.), Systems Thinking. Penguin, Harmondsworth, pp. 281-296.

Figge, F., Hahn, T., Schaltegger, S., Wagner, M. (2002). The sustainability balanced scorecard-linking sustainability management to business strategy. Business Strategy and the Environment 11(5), 269-284.

Gond et al. (2010). Accounting, Auditing and Control for Sustainability Track of the 2010 EURAM annual conference.

Gond,J.-P.,Grubnic,S.,Herzig,C.,Moon,J. (2012). Configuringmanagement control systems: theorizing the integration of strategy and sustainability. Management Accounting Research 23, 205-223.

Gray, R. (2010). Is accounting for sustainability actually accounting for sustainability. And how would we know? An exploration of narratives of organisations and the planet. Accounting, Organizations and Society 35, 47-62.

GRI. (2006). Sustainability Reporting Guidelines. GRI, Amsterdam.

Henri, J.-F., Journault, M. (2010). Eco-control: the influence of management control systems on environmental and economic performance. Accounting, Organizations and Society 35, 63-80.

Herremans, I. M., J. A. Nazari, and F. Mahmoudian. (2015). Stakeholder Relationships,

Engagement, and Sustainability Reporting. Journal of Business Ethics: 1-19

https://www.scimagojr.com/journalrank.php?category=1402 (accessed 25.08.2017)

https://www.journals.elsevier.com/management-accounting-research (accessed 25.08.2017)

https://aaapubs.org/loi/jmar?code=aaan-site (accessed 25.08.2017)

Herzig, C., Viere, T., Schaltegger, S., Burritt, R. (2012). Environmental Management Accounting. Case Studies of South East-Asian Companies. Routledge, London.

Hopwood, A.G., Unerman, J., Fries, J. (Eds.). (2010). Accounting for Sustainability: Practical Insights. Earthscan, London.

* Corresponding author's e-mail: cuynit@yahoo.com http://openjournal.unpam.ac.id/index.php/JABI 
Jurnal Akuntansi Berkelanjutan Indonesia - Vol. 4, No. 1, Jan 2021 - SeTin; Setiawan \& Christy

Hubbard, G. (2009). Measuring organizational performance: beyond the triple bottom line. Business Strategy and the Environment 18(3), 177-191.

Ittner, C.D., Larcker, D.F. (2001). Assessing empirical research in managerial accounting: a value-based management perspective. J. Account. Econ. 32 (1-3), $349-410$

Langfield-Smith, K. (1997). Management control systems and strategy: a critical review. Accounting, Organizations and Society 22(2), 207-232

Malmi, T., Brown, D.A. (2008). Management control systems as a packageopportunities, challenges and research directions. Management Accounting Research 19(4), 287-300.

O'Dwyer, B. (2005). The construction of a social account: a case study in an overseas aid agency. Accounting, Organizations and Society 30, 279-296

Norris, G., O'Dwyer, B. (2004). Motivating socially responsive decision making: the operation of management controls in a socially responsive organisation. British Accounting Review 36, 173-196.

Perego, P., Hartmann, F. (2009). Aligning performance measurement systems with strategy: the case of environmental strategy. ABACUS 45 (4), 397-428.

Pérez-López, D., A. Moreno-Romero, and R. Barkemeyer. (2013). Exploring the Relationship between Sustainability Reporting and Sustainability Management Practices. Business Strategy and the Environment: n/a-n/a

Porter M.E., \& Kramer M R. (2007). Strategy and Society: The Link Between Competitive Advantage and Corporate Social Responsibility. Issue of Harvard Business Review. 84(12):78-92, 163 .

Rahbek Pedersen, E., \& Neergaard, P. (2008). From periphery to center: how CSR is integrated in mainstream performance management frameworks. Measuring Business Excellence, 12(1), 4-12.

Roth, H.P. (2008). Using cost management for sustainability efforts. Journal of Corporate Accounting \& Finance 19(3), 11-18

Schaltegger, S., Wagner, M. (2006). Integrative management of sustainability performance, measurement and reporting. International Journal of Accounting, Auditing and Performance Evaluation 3(1), 1-19.

Schaltegger, S., Burritt, R.L. (2010). Sustainability accounting for companies. Catchphrase or decision support for business leaders? Journal of World Business $45,375-384$.

* Corresponding author's e-mail: cuynit@yahoo.com http://openjournal.unpam.ac.id/index.php/JABI 
Jurnal Akuntansi Berkelanjutan Indonesia - Vol. 4, No. 1, Jan 2021 - SeTin; Setiawan \& Christy

Searcy, C. (2012). Corporate sustainability performance measurement systems: A review and research agenda. Journal of Business Ethics 107 (3): 239-253.

Simons, R. (1995). Levers of Control: How Managers use Innovative Control Systems to Drive Strategic Renewal. Harvard Business School Press, Boston.

Simons, R. (2006). Levers of Organization Design: How Managers Use Accountability Systems for Greater Performance and Commitment. Harvard Business School Press, Boston

Schmidt, I., Meurer, M., Saling, P., Kicherer, A., Reuter, W., Gensch, C. (2004). SEEBALANCE - managing sustainability of products and processes with the socio-eco-efficiency analysis by BASF. Greener Management International 45,79-94

Smith, P. and Sharicz, C. (2011), The shift needed for sustainability, the learning organization. Emerald Insight, 18(1)1, 73-86.

Thornton, p. H., and W. Ocasio. (2008). Institutional logics. In Handbook of Organizational Institutionalism, edited by Greenwood' R.' C. Oliver, R. Suddaby, and K. Sahlin-Andersson. Thousand Oaks, CA: Sage Publications.

Wood, V. R., and K. R. Robertson. (1997). Strategic orientation and export success: An empirical study. International Marketing Review 14(6):424-r'!!.

Yuan, W., Y. Bao, and A. Verbeke. 2011. Integrating CSR initiatives in business: An organizing framework. Journal of Business Ethics 101:75-92.

Wahyuni, E.T. (2015). Tuntutan Pelaporan Keuangan Semakin Kompleks: Tantangan Masa Depan Akuntan. Majalah CPA Indonesia edisi Maret 2015. http://csrindonesia.com/tantangan-peluang-perkembangan-csr-indonesia/.

* Corresponding author's e-mail: cuynit@yahoo.com http://openjournal.unpam.ac.id/index.php/JABI 